\title{
Impact of the biological control agent Mesoclanis polana (Tephritidae) on bitou bush (Chrysanthemoides monilifera subsp. rotundata) in eastern Australia
}

\author{
P.B. Edwards ${ }^{1,2 *}$, R.J. Adair ${ }^{3}$, R.H. Holtkamp ${ }^{4}$, \\ W.J. Wanjura ${ }^{1}$, A.S. Bruzzese ${ }^{3}$ and R.I. Forrester ${ }^{5}$ \\ ${ }^{1}$ CRC for Australian Weed Management, CSIRO Entomology, GPO Box \\ 1700, Canberra ACT 2601, Australia; ${ }^{2}$ Current address: PO Box 865, \\ Maleny, Queensland 4552, Australia: ${ }^{3}$ Department of Primary Industries, \\ PO Box 48, Frankston, Victoria 3199, Australia: ${ }^{4}$ NSW Department of \\ Primary Industries, CRC for Australian Weed Management, 4 Marsden \\ Park Road, Tamworth 2340, Australia: ${ }^{5}$ CSIRO Entomology, GPO Box \\ 1700, Canberra ACT 2601
}

\begin{abstract}
The seed fly Mesoclanis polana (Diptera: Tephritidae) was released in Australia in 1996. Its impact on seed production of bitou bush (Chrysanthemoides monilifera subsp. rotundata) was monitored at eight sites along the New South Wales coast from 1996 to 2004. Peak flowerhead production occurred in autumn (March to May); therefore, samples collected in May of each year were used to compare abundance and impact of M. polana across sites and between years. Latitude had a significant effect on abundance and impact of M. polana. By May 2004, 99.6\% of flowerheads at the five most northern sites contained at least one egg, while $64 \%$ of flowerheads from the two most southern sites contained at least one egg. In May 2004, mean numbers of M. polana eggs per flowerhead were between 13 and 17 at four of the six northern sites and below two at the two southern sites. In May 2004, average seed destruction by M. polana was $58 \%$ at the four most northern sites and $11 \%$ at the two most southern sites. The highest level of seed destruction recorded was $86 \%$ at Kingscliff in May 2003. Percentage seed destruction in May provided a reasonable estimate of seed destruction for the whole year. Parasitoids were found throughout the range of M. polana in Australia. Their attack rate on M. polana was less than $10 \%$ at all sites, except at the two most northern sites where parasitism of up to $27 \%$ was recorded. Parasitism results are compared with predictions made following an earlier study. The release of Mesoclanis magnipalpis, a species suited to cooler environments, is recommended for the southern range of $C$. monilifera subsp. rotundata.
\end{abstract}

Keywords: Mesoclanis, Chrysanthemoides, biological control, parasitism, impact, seed production, weed, tephritid, evaluation, latitudinal gradient

(Accepted 20 March 2008)

*Author for correspondence

Fax: + 61754943175

E-mail: pbe@aapt.net.au 


\section{Introduction}

The South African shrub Chrysanthemoides monilifera (L.) T. Norl. (Asteraceae) is one of 20 Weeds of National Significance in Australia (ARMCANZ, 2000). It threatens biodiversity and natural resource assets, particularly in coastal ecosystems of the eastern Australian seaboard. In New South Wales (NSW), C. monilifera subsp. rotundata (DC) T. Norl. (hereafter C. m. rotundata), known as bitou bush, occurs along $80 \%$ of the coastline (Holtkamp et al., 1999), and its distribution is increasing (Thomas \& Leys, 2002). Chrysanthemoides monilifera subsp. monilifera (hereafter C. $m$. monilifera), known as boneseed, occurs in temperate regions of the southern states of Victoria, South Australia and Tasmania and, to a limited extent, in NSW and Western Australia (Weiss et al., 2008). Both subspecies of C. monilifera are subject to classical biological control in Australia, and eight species of arthropods have been tested for host specificity and released since 1987 . Four species are known to have established (Downey et al., 2007). Additional arthropods and pathogens are under consideration for assessment and possible introduction (Adair \& Edwards, 1996).

The seed-feeding tephritid Mesoclanis polana Munro is native to South Africa, where it is restricted to C. $m$. rotundata (Edwards \& Brown, 1997). In 1996, it was approved for release in Australia (Adair \& Bruzzese, 2000). It established and dispersed readily, and now occurs throughout the distribution of C. m. rotundata in coastal NSW (Edwards et al., 1999).

Seed-feeders have the potential to play an important role in modifying plant populations (Louda, 1989; Crawley, 1992; Louda \& Potvin, 1995; Hoffmann \& Moran, 1998) and can impose strong selection pressure on their hosts (Louda, 1982; Maron \& Gardner, 2000). Seed-feeders are often used as biocontrol agents for weeds (Julien \& Griffiths, 1998), and their use can be attributed to factors such as high levels of host specificity, ease of rearing and the avoidance of conflicts of interest where vegetative parts of the host have value (van Klinken et al., 2004).

The paucity of case studies to quantify the effects of seedfeeding agents on the population dynamics of weeds contributes to uncertainty about the merits of this guild of agents as biological control agents (van Klinken et al., 2004). Although dramatic declines in weed populations have been attributed to seed-feeding insects (Louda \& Potvin, 1995; Hoffmann \& Moran, 1998), there are relatively few examples where significant impact has been observed.

Population modelling and field observations suggest seed predation rates need to be very high to regulate plant populations (Myers \& Risley, 2000; Sheppard et al., 2002; Buckley et al., 2005). This is particularly the case with invasive plants, as they are mostly micro-site limited (Crawley, 1992) rather than seed-limited. Seed-destruction levels in excess of $95 \%$ may be required for effective suppression of C. m. rotundata (Noble \& Weiss, 1989). In South Africa, M. polana can cause substantial reduction in viable seed production (Edwards \& Brown, 1997), but variability in seed destruction between sites is high, mitigated, among other factors, by attack from hymenopteran parasitoids (Edwards, 1998).

Seed-feeders are likely to reduce invasion rates of weeds (Neser \& Kluge, 1986; Zimmermann, 1992; van Klinken et al., 2004) although the impact will be dependent on seed dispersal mechanisms and landscape heterogeneity. It is considered that commonly observed seed predation rates may be sufficient to significantly reduce invasion rates of weeds (van Klinken et al., in press).

As seed predation levels can vary spatially over climatic gradients (Louda, 1982, 1983) and show strong seasonal variation (Moore, 1978; Sperens, 1997), assessing seed destruction levels from multiple and dispersed locations is required for monitoring or modelling plant species with wide ecological or latitudinal distributions.

In the study reported here, M. polana impact on C. $m$. rotundata seed production is reported from eight sites in NSW throughout the plant's range from 1996 (the year of release) to 2004. The flowering phenology of bitou bush was studied at each site, so that the main period of flowerhead production could be determined and the annual rate of seed destruction calculated. Incidence of parasitism of M. polana by native parasitoids was also recorded. Parasitism data were compared with pre-release predictions made by Edwards et al. (1996).

This long-term study highlights temporal and spatial variation in seed destruction by $M$. polana in Australia. Results are used to suggest future directions for biological suppression of C. monilifera in Australia.

\section{Methods}

Study species

Chrysanthemoides $m$. rotundata flowerheads comprise a central area of disc florets, surrounded by a single ring of up to 13 female ray florets. The ray florets develop into large fleshy drupes, each containing a single woody seed. Nine stages of flowerhead development are recognised (stage 0 to stage 8: Edwards \& Brown, 1997).

Mesoclanis polana females lay eggs into flowerheads from stage 1 (involucral bracts still completely enclosing florets, 'bud' at half maximum size) to stage 5 (ray florets extending beyond bracts, but not yet at full length). Each female lays one or two eggs per flowerhead, and several females may lay in the same flowerhead (Edwards \& Brown, 1997). Larvae feed within florets and developing ovules, eventually pupating in ovules of stage 8 flowerheads (green fruit, full size but not ripe), or occasionally in receptacles (Edwards \& Brown, 1997). Under glasshouse conditions, females on average lay 56 eggs, and egg to adult development takes approximately five weeks (Adair \& Bruzzese, 2000).

\section{Study sites}

Sampling of C. $m$. rotundata was undertaken at eight sites along the NSW coast: Fingal $\left(28^{\circ} 13^{\prime} \mathrm{S}, 153^{\circ} 34^{\prime} \mathrm{E}\right)$, Kingscliff $\left(28^{\circ} 16^{\prime} \mathrm{S}, 153^{\circ} 35^{\prime} \mathrm{E}\right)$, Ballina $\left(28^{\circ} 53^{\prime} \mathrm{S}, 153^{\circ} 34^{\prime} \mathrm{E}\right)$, Coffs Harbour (Bongil Bongil National Park $30^{\circ} 25^{\prime} \mathrm{S}$, $153^{\circ} 04^{\prime} \mathrm{E}$ ), Port Macquarie (Mermaid Beach in Crowdy Bay National Park $31^{\circ} 45^{\prime} \mathrm{S}, 152^{\circ} 46^{\prime} \mathrm{E}$ ), Sydney (Botany Bay National Park $34^{\circ} 02^{\prime} \mathrm{S}, 151^{\circ} 11^{\prime} \mathrm{E}$ ), Jervis Bay (Booderee National Park $35^{\circ} 10^{\prime} \mathrm{S}, 150^{\circ} 40^{\prime} \mathrm{E}$ ) and Moruya (Eurobodalla National Park $35^{\circ} 53^{\prime} S, 150^{\circ} 09^{\prime}$ E) (fig. 1). Samples were taken from 1996 to 2004. The frequency of visits, duration of the sampling program and number of samples collected varied between sites. Generally, samples were taken every two months from 1996 to 1999 and annually thereafter. Monthly samples were collected for one year (2000-2001) at Kingscliff. 


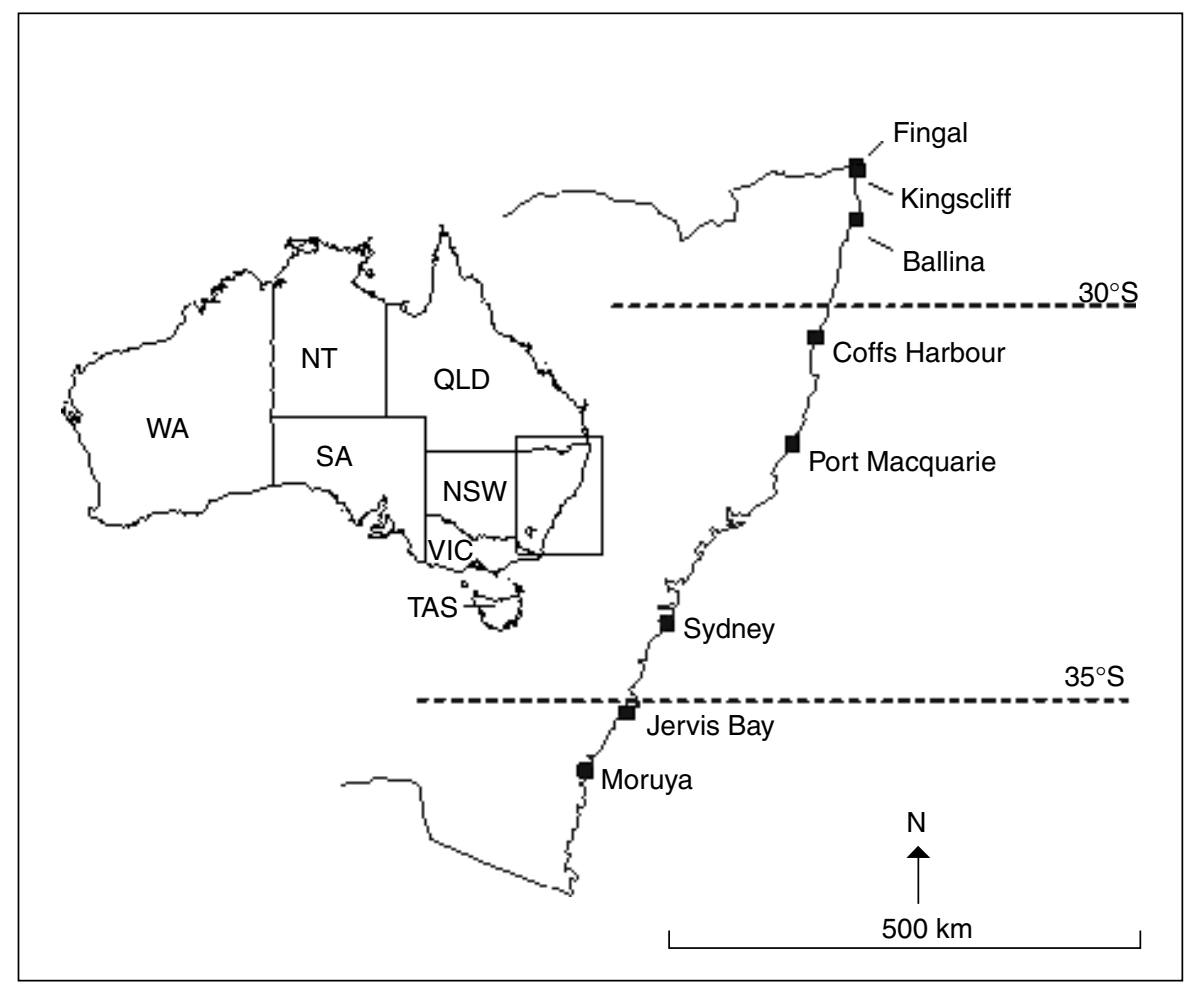

Fig. 1. Location of sampling sites along the New South Wales coast. (NSW, New South Wales; VIC, Victoria; TAS, Tasmania; SA, South Australia; WA, Western Australia; NT, Northern Territory; QLD, Queensland).

\section{Reproductive phenology of bitou bush}

Reproductive status of $C$. $m$. rotundata was assessed on each visit using a crown sampler, a circular aluminium frame of diameter $23.5 \mathrm{~cm}$, with six $30 \mathrm{~cm}$-long projecting rods that defined a cylinder $23.5 \times 30 \mathrm{~cm}$. The frame was placed in the C. $m$. rotundata canopy, and the numbers of buds (stages 2-6), flowers (stage 7), green fruit (stage 8) and ripe fruit within the crown sampler were counted. At Ballina, Coffs Harbour and Port Macquarie, 20 samples were taken along a $50 \mathrm{~m}$ transect through a C. $\mathrm{m}$. rotundata infestation. At other sites, two samples were taken from either five or ten bushes (giving ten or 20 samples per site). At all sites, samples were taken haphazardly, although obvious gaps in the canopy were avoided. Results were converted to counts per square metre of canopy.

\section{Monitoring M. polana oviposition}

On each visit to a site, samples of stage 6 flowerheads (ray florets at full length, laminae not unfurled) were collected into white vinegar. Vinegar was used to preserve samples in a soft state for dissection, and to enable samples to be returned to the laboratory by mail. Ten or 20 flowerheads were collected from each bush, and samples were taken from five, ten or 20 bushes. (Initially, a total of 400 flowerheads was collected, but it was found that 50 flowerheads were sufficient to provide reliable estimates of egg numbers). Flowerheads were dissected under a microscope, and numbers of $M$. polana eggs (hatched and unhatched) were recorded.

\section{Ovule and seed damage by M. polana larvae}

Samples of stage 8 flowerheads (green fruit) were collected into vinegar for dissection to determine predispersal seed damage caused by $M$. polana larval feeding. Ten (or 20) flowerheads were collected from either five or ten bushes at each site. The number of ovules damaged per flowerhead was recorded. This included three categories of ovules: (i) those that were fully developed, (ii) those that were partially developed, and (iii) those that had not developed at all. A proportion of undeveloped ovules do not develop into seeds, irrespective of the presence of $M$. polana, and their inclusion in damage estimates may be misleading. Therefore, seed damage was calculated as the percentage of fully and partially developed ovules damaged by M. polana.

\section{Parasitism of $\mathrm{M}$. polana larvae}

Samples of stage 8 flowerheads (green fruit) were collected into small plastic ventilated containers for subsequent emergence of $M$. polana adults and parasitoids in the laboratory. Ten (or 20) flowerheads were collected from five (or ten) plants at each site. Containers were checked after about one month, or when no more insects emerged from samples, and flies and parasitoids were identified and counted. This method detected parasitoids of M. polana larvae and pupae, but not of eggs. The estimates of parasitism are slightly imprecise since not all parasites and not all $M$. polana adults emerged from fruit samples stored in the laboratory. However, it is likely that this effect was consistent between samples. 


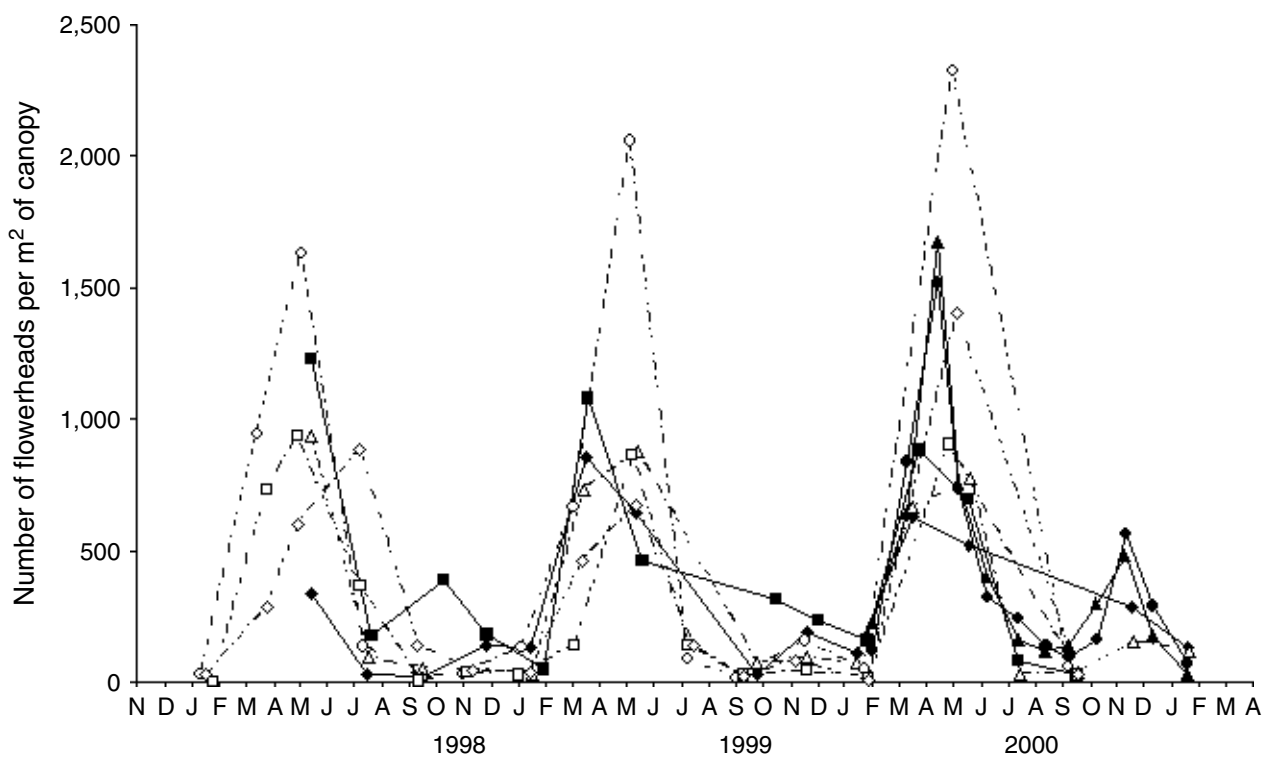

Fig. 2. Density of bitou bush flowerheads at eight sites along the NSW coast (estimates derived from ten canopy samples on each occasion at Fingal, Kingscliff, Sydney, Jervis Bay and Moruya; 20 canopy samples at Ballina, Coffs Harbour, Port Macquarie) (- - ,

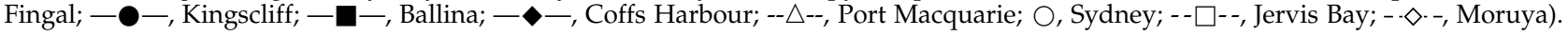

Parasitism data from a study in South Africa (see Edwards et al., 1996; Edwards, 1998) are included with the results so that a comparison can be made with the situation in Australia.

\section{Results}

\section{Bitou bush flowering phenology}

Flowerhead densities at eight sites along the NSW coast over a three-year period are shown in fig. 2. The pattern of abundance was similar at all sites, with a large peak in flowerhead numbers in autumn (March to May) and a smaller peak in spring (around November). The secondary peak in spring tended to be larger at the northern sites than at the southern sites. The maximum density of flowerheads was highest in Sydney in all three years, reaching 2325 per square metre in May 2000.

Monthly samples were collected at Kingscliff from February 2000 to January 2001, providing more precise data on flowering phenology. Flowerheads were present in all months at Kingscliff, with highest numbers in March to May. The secondary peak in November was about a third the size of the main peak. Bud numbers (stages 2-6) were highest in March, flowers (stage 7) and green fruit (stage 8) in April, and ripe fruit in May. Thus, at Kingscliff, the duration from the bud stage to green fruit was approximately one month.

Peak flowerhead production occurred slightly later at the more southerly sites (dotted lines in fig. 2) than at the northern sites (solid lines). Peak bud numbers in March and green fruit in May was the most common pattern seen at most sites south of Kingscliff.

\section{Proportion of flowerheads attacked by M. polana}

The proportion of flowerheads containing $M$. polana eggs reflects the searching success of $M$. polana females. The percentage of stage 6 flowerheads in May (a time of high flowerhead production) that contained one or more eggs is shown in fig. 3.

Eggs were first recorded in 1997, the year following the release of $M$. polana. There was a rapid increase in the proportion of buds attacked in 1998; and, from 1999 onwards, more than $70 \%$ of flowerheads were attacked. The proportion of flowerheads attacked at the five most northerly sites averaged 99.3\% in May 2003 and 99.6\% in May 2004. In contrast, at the two most southerly sites (Jervis Bay and Moruya), attack rates declined after 1999 and averaged 35\% in May 2003 and 64\% in May 2004.

\section{Within-year changes in M. polana egg density}

The number of $M$. polana eggs laid into each flowerhead varied during the year, due to changing flowerhead densities and changing fly densities. At Kingscliff, monthly samples were taken from February 2000 to January 2001.

The mean number of $M$. polana eggs per flowerhead at Kingscliff was highest in summer, with between nine and 12 eggs per flowerhead in December and January, compared with fewer than four for the rest of the year (fig. 4). By contrast, the greatest egg density per $\mathrm{m}^{2}$ occurred in March, with a second smaller peak in November. These patterns reflect the peaks in flowerhead production.

\section{Abundance of M. polana eggs in Bitou Bush flowerheads}

The impact of M. polana on bitou bush seed production is largely determined by the number of eggs laid in each flowerhead. Mean numbers of eggs per flowerhead in May of each year are shown in fig. 5 .

In the first three years after establishment of M. polana, mean numbers of eggs per flowerhead in May ranged 


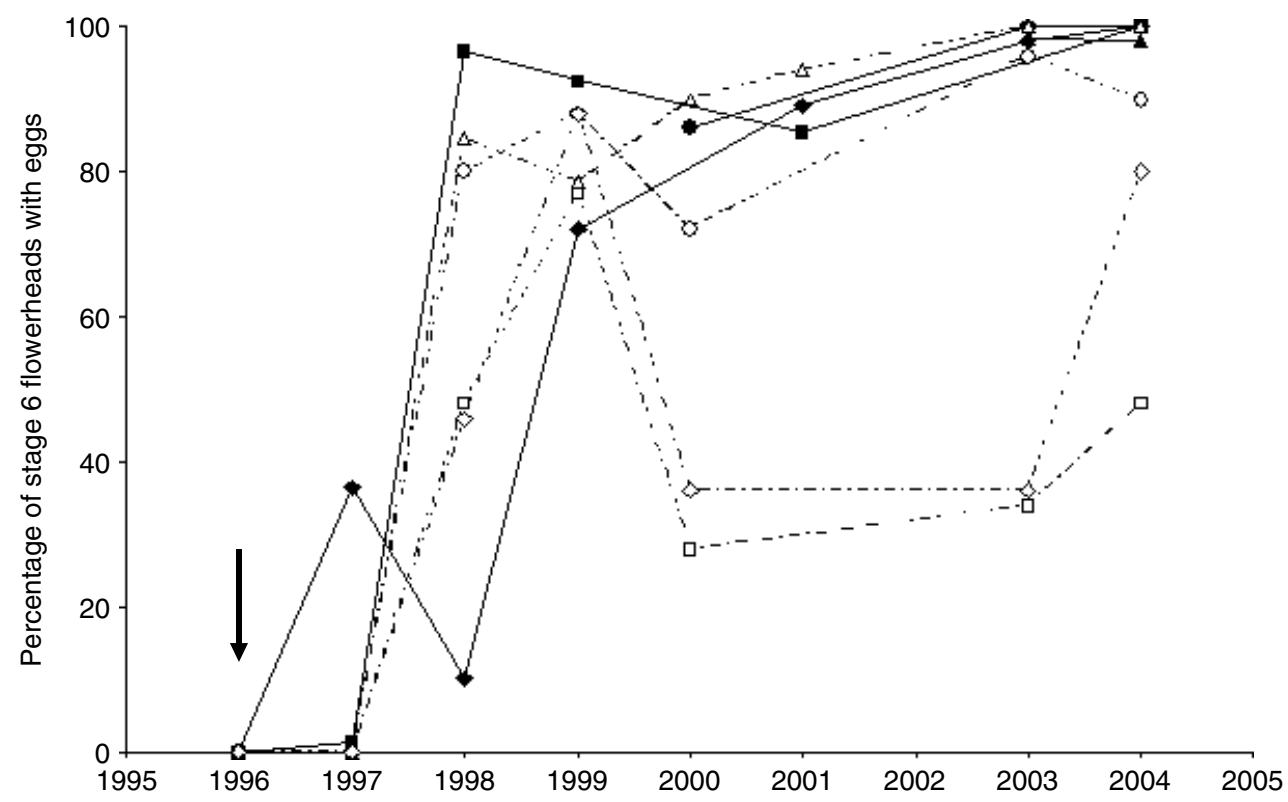

Fig. 3. Percentage of stage 6 bitou bush flowerheads with one or more M. polana eggs (May samples only) (samples sizes between 50 and 400 flowerheads on each occasion). Arrow indicates year of release of M. polana ( $-\mathbf{\Delta}-$, Fingal; $-\mathbf{-}-$, Kingscliff; $-\mathbf{\square}-$, Ballina; $-\downarrow$, Coffs Harbour; -- $\triangle--$, Port Macquarie; $\bigcirc$, Sydney; -- $\square--$, Jervis Bay; - $\diamond--$, Moruya).

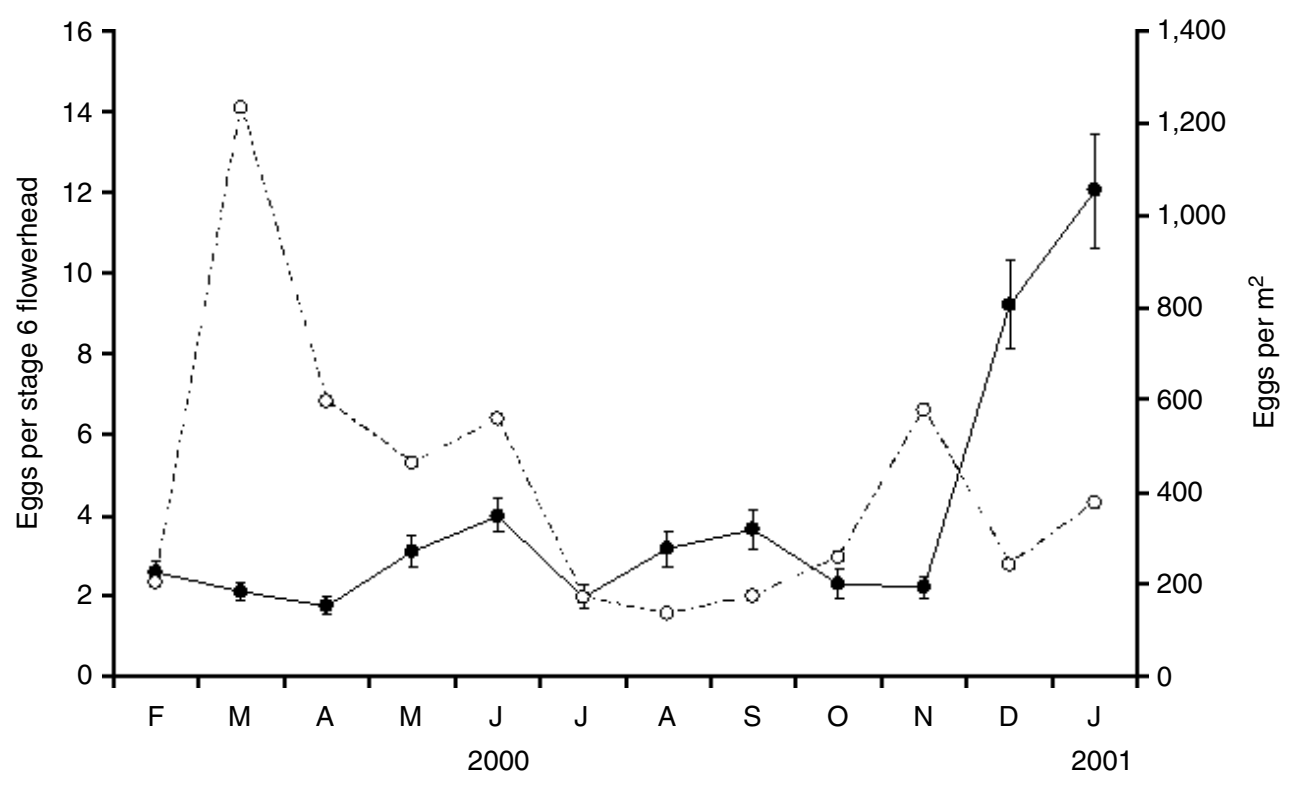

Fig. 4. Within-year changes in numbers of Mesoclanis polana eggs per stage 6 flowerhead ( \pm SE) and per $\mathrm{m}^{2}$ at Kingscliff $2000-2001$ (samples of 50 flowerheads on each occasion) (- - Eggs per flowerhead; - -,-- , eggs per square metre).

from 0.3 to 5.4 (fig. 5). By 2004, there were considerable differences between sites. In May 2004, ten flowerheads were sampled from five plants at each of the eight sites (total $n=400)$. The number of eggs per flowerhead was $\ln (n+1)$ transformed and a nested analysis of variance carried out using Genstat (Payne et al., 2007). The estimated variance components and their standard errors (in parentheses) are: between sites, 0.7731 (0.4222); between bushes within sites,
0.0549 (0.0209); between flower heads within bushes within sites, 0.281 (0.021). A quadratic regression for the site means was fitted against longitude (i.e. distance in $\mathrm{km}$ from the most northerly site) and plotted in fig. 6 . The model indicates that there was a significant effect of latitude, with egg numbers declining rapidly towards the south (linear effect: $\mathrm{F}=16.67, \quad P=0.009, \quad \mathrm{df}=1,5 ;$ quadratic effect: $\mathrm{F}=5.65$, $P=0.064, \mathrm{df} 1,5)$. The quadratic effect does not quite 


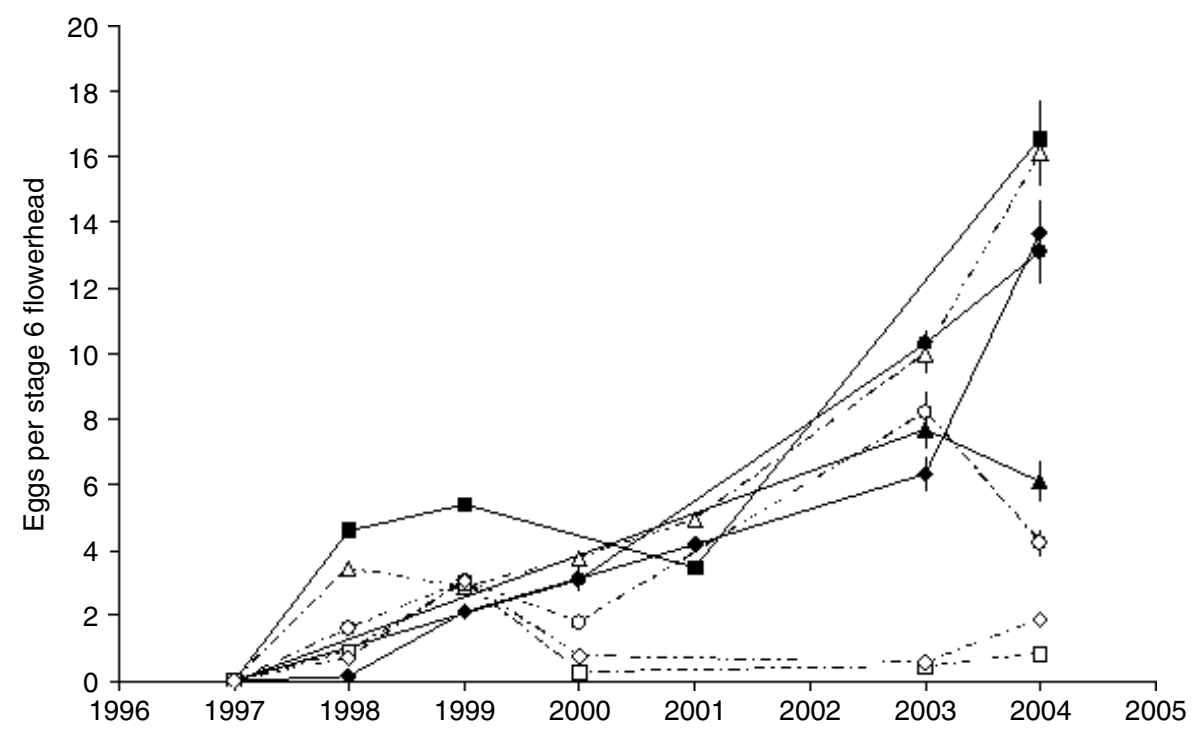

Fig. 5. Mean number of M. polana eggs per bitou bush flowerhead (May samples only) (samples sizes between 50 and 400 flowerheads on each occasion). Error bars $( \pm \mathrm{SE})$ are included for all points. In many cases, the symbols are larger than the error bars $(-\mathbf{0}$,

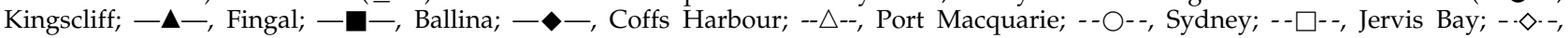
Moruya).

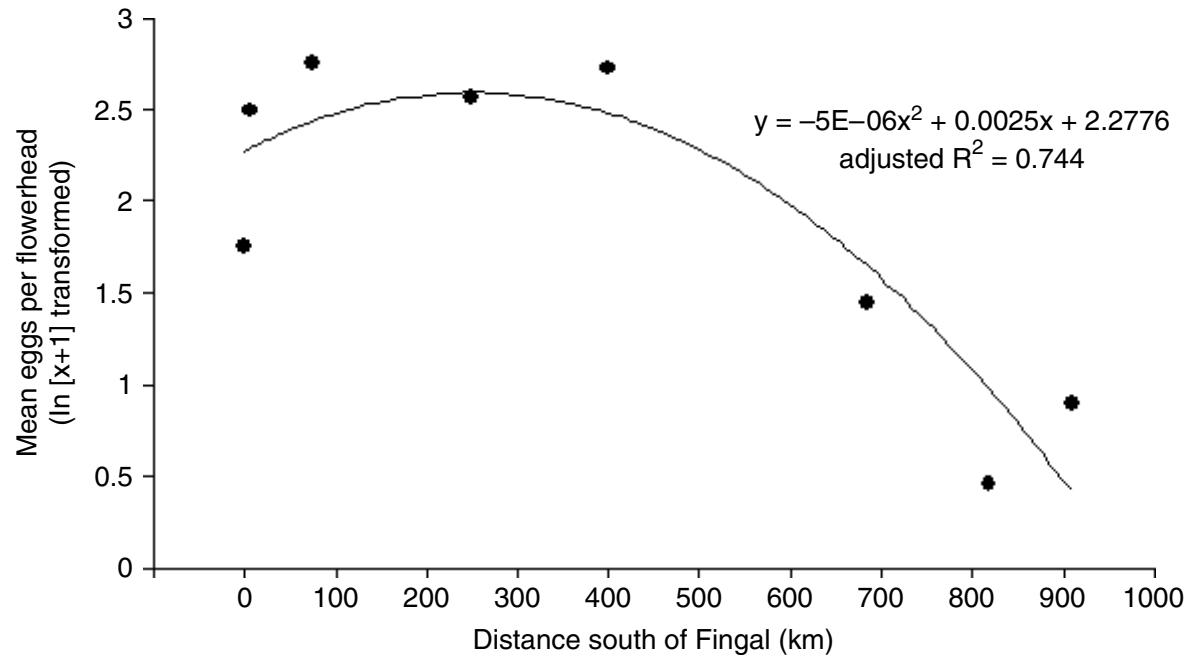

Fig. 6. Mean number of M. polana eggs per bitou bush flowerhead in May 2004 at eight sites on the east coast of Australia. The quadratic model was fitted using all data points (50 flowerheads per site).

reach statistical significance, but this is largely due to the small number of degrees of freedom used in the testing process.

\section{Seed damaged by M. polana}

Percentage of seeds damaged by M. polana

The percentage of 'seeds' (i.e. developed and developing ovules only) damaged by $M$. polana in May each year is presented in fig. 7. An early peak in damage occurred in 1998 at the northern sites and in 1999 at the southern sites. The highest impact at this time was $58 \%$ at Ballina in 1998. Thereafter, damage increased at more northerly sites and decreased at southerly sites. The highest level of seed destruction was $86 \%$ recorded at Kingscliff in 2003, and the lowest was $2 \%$ at Jervis Bay in 2003. Average seed destruction in May at the four most northerly sites was 55\% in May 2003 and 58\% in May 2004. At the two most southerly sites, damage averaged 6\% in May 2003 and $11 \%$ in May 2004.

In May 2004, ten flowerheads were sampled from five plants at each of the eight sites. For each flowerhead, the proportion of ovules (fully developed and partially 


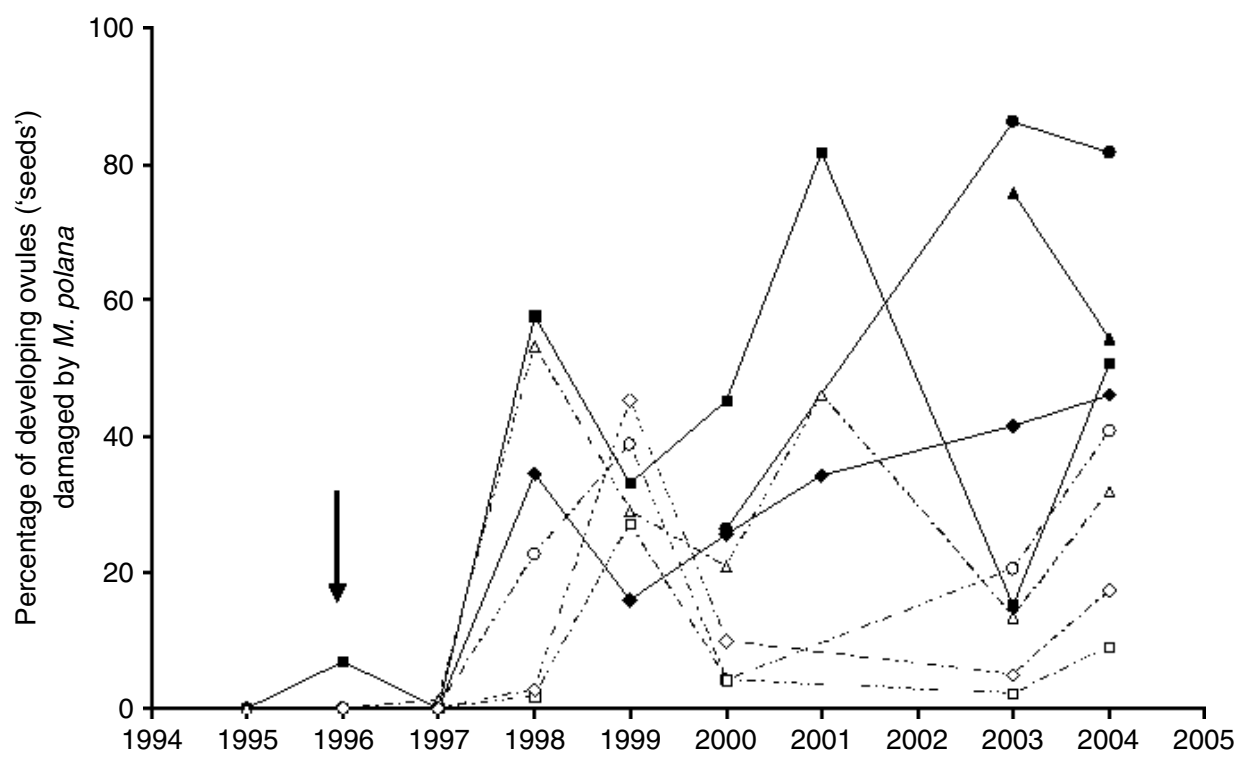

Fig. 7. Percentage of developing bitou bush seeds damaged by M. polana larvae (May samples only) (samples of between 50 and 100

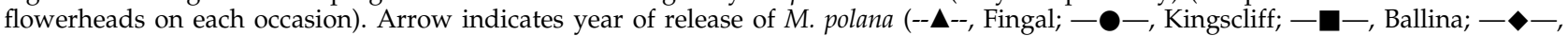
Coffs Harbour; -- $\triangle--$, Port Macquarie; -- $\bigcirc--$, Sydney; -- $\square--$, Jervis Bay; - $\diamond--$, Moruya).

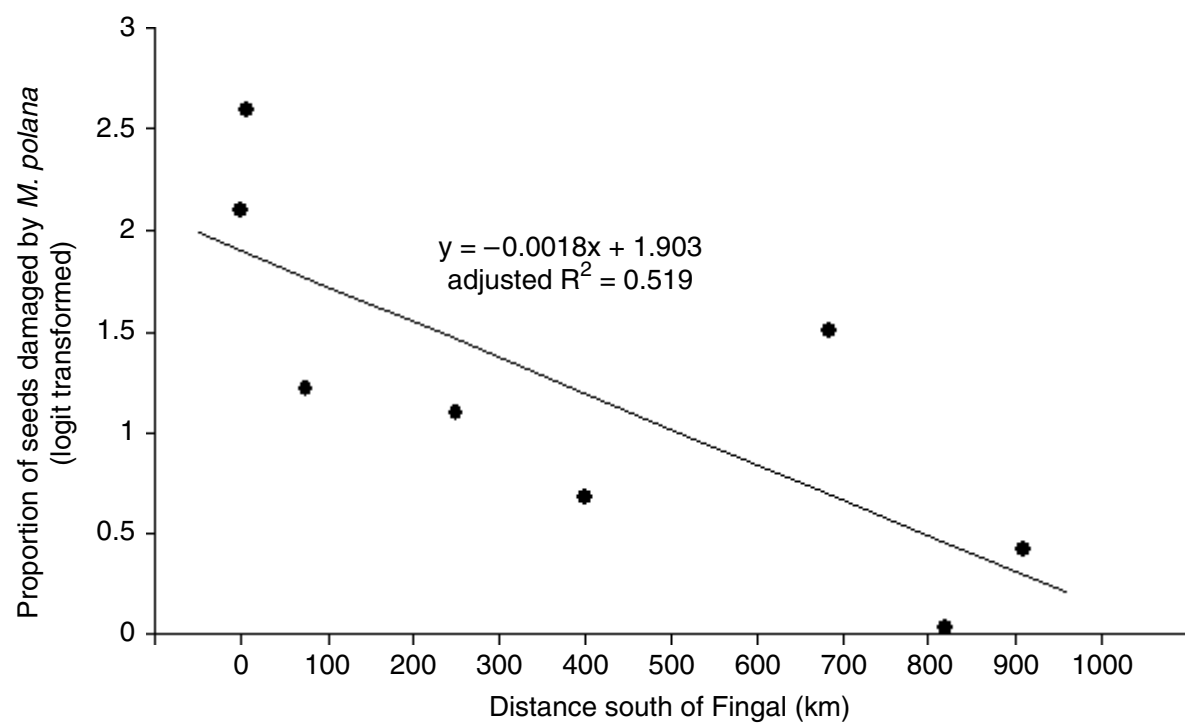

Fig. 8. Relationship between latitude ( $\mathrm{km}$ south of Fingal) and the proportion of bitou bush seeds damaged by M. polana larvae. The regression model was fitted using all data points (50 flowerheads per site), but only means are plotted in the figure.

developed) damaged by M. polana (x) was calculated. The data were logit transformed using $\ln (x /(1-x))$. Any zeroes were replaced by $0.5 \times \min (x)$ and any ones were replaced by $1-0.5 \times(1-\max (x))$, where $\min (x)$ and $\max (x)$ are the minimum and maximum values that are not equal to either 0 or 1.

A linear regression of the effect of latitude (i.e. distance in $\mathrm{km}$ from the most northerly site) on the proportion of seeds damaged by M. polana was fitted to these data using Genstat (Payne et al., 2007). The regression indicated that there was a significant decrease in impact from north to south $(F=8.55$; $\mathrm{df}=1,6 ; P=0.027)$. To illustrate the relationship, the regression line is plotted in fig. 8 against the means for each site.

Total annual pre-dispersal seed production damaged by M. polana

The damage assessments (above) were made from samples collected in May, as this is a time of year when seed production is high. However, it is important to know how this relates to the impact of $M$. polana on annual seed production. 

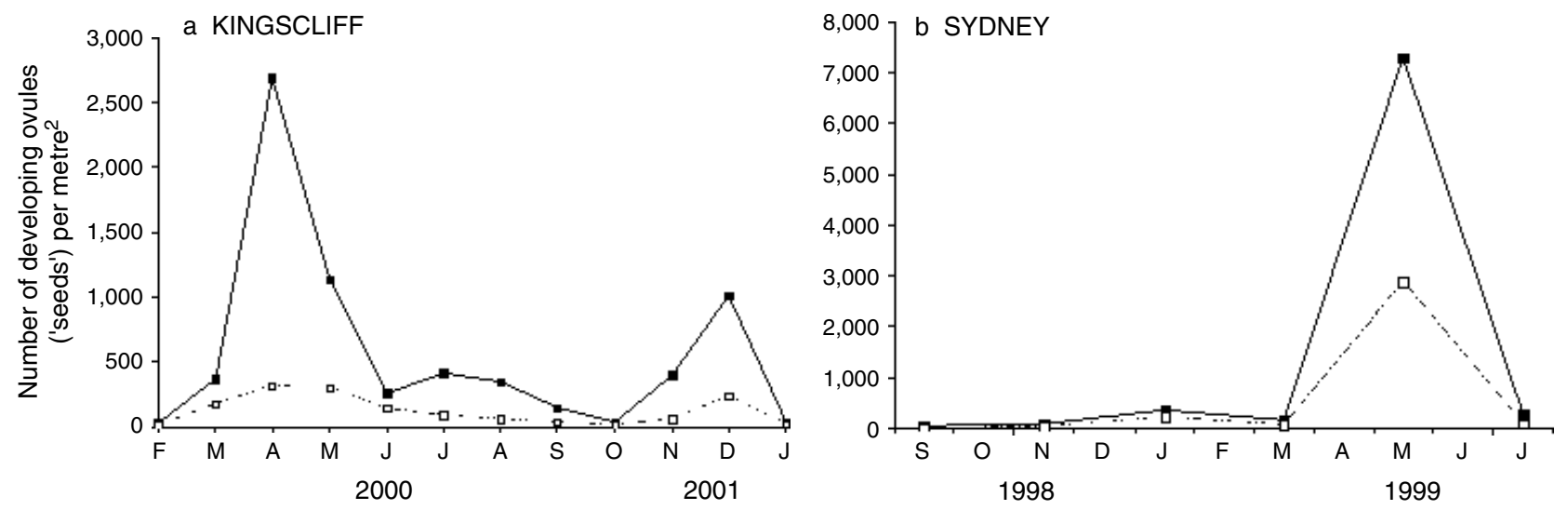

Fig. 9. Within-year damage caused by M. polana larvae to developing seeds of bitou bush at (a) Kingscliff 2000-2001 (estimates derived from ten canopy samples and 50 flowerheads on each occasion) and (b) Sydney 1998-1999 (estimates derived from ten canopy samples and 100 flowerheads on each occasion, except Sept. 1998 when only 12 flowerheads were collected) (一 $\square$, total seeds per square metre; $-\square$ - damaged seed per square metre).

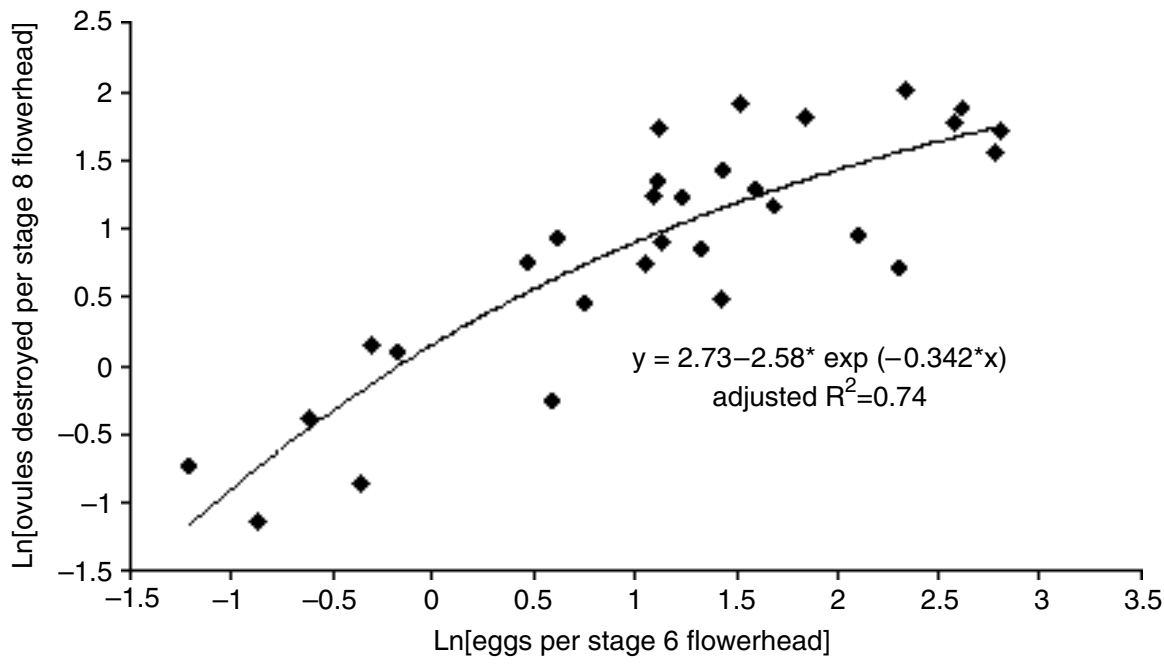

Fig. 10. Relationship between the number of M. polana eggs per stage 6 flowerhead and the number of ovules destroyed per stage 8 flowerhead in May samples from all sites from 1997 to 2004 . Each point is the mean of all flowerheads collected at a particular site on each occasion (minimum of 50 flowerheads per sample).

At Kingscliff, numbers of damaged and undamaged 'seeds' (i.e. fully developed and partly developed ovules only) were determined from samples taken each month from February 2000 to January 2001 and converted to numbers per $\mathrm{m}^{2}$ (fig. 9a). The main peak in seed production at Kingscliff occurred in April. The total annual seed damaged was $21.3 \%$ (total for 12 months of 1463/6879 ovules). By comparison, seed damage in May 2000 was 26.4\% (fig. 7). Thus, the May figure provided a reasonable estimate of annual damage, despite ovule production in May representing only $17 \%$ of the annual total.

At Sydney, total annual damage was calculated to be $39.5 \%$, based on summations for six samples taken during 1998/99 (fig. 9b). This is very close to the May 1999 estimate of $39.3 \%$ (fig. 7 ), which is a reflection of the fact that a very high proportion of the annual seed total (89\%) was collected in this month.

\section{Comparison of egg numbers and ovule damage}

The relationship between the mean number of $M$. polana eggs in a flowerhead and the mean number of ovules per flowerhead damaged by M. polana was examined for all samples collected in May of any year (fig. 10). (Note that damage was not recorded from the same flowerheads that contained the eggs but from a sample of stage 8 flowerheads (i.e. green fruit) collected at the same time.)

Data were ln transformed and an exponential regression model fitted using Genstat (Payne et al., 2007) with a single outlier omitted. The fitted model was $y=2.73-$ $2.58^{*} \exp \left(-0.342^{*} \mathrm{x}\right)$, which accounted for $74.0 \%$ of the variance. The relationship is highly significant $(P<0.001)$. The number of ovules destroyed approaches an asymptote of 2.73 at higher egg numbers. This levelling off is not surprising since the maximum number of ovules per 
Table 1. Comparison of parasitism of Mesoclanis species in Australia (this study) and South Africa. The proportion of parasitoids from each taxonomic grouping is indicated as a percentage of all parasitoids reared from Mesoclanis at each site. At all Australian sites, and at St Lucia, Mtunzini and Durban in South Africa, the insect-plant system is Mesoclanis polana on C. $m$ rotundata. At St Francis Bay in South Africa, it is M. magnipalpis and M. dubia on C. m. rotundata. At De Hoop, it is M. magnipalpis on C. m. pisifera (see Edwards et al., 1996; Edwards, 1998).

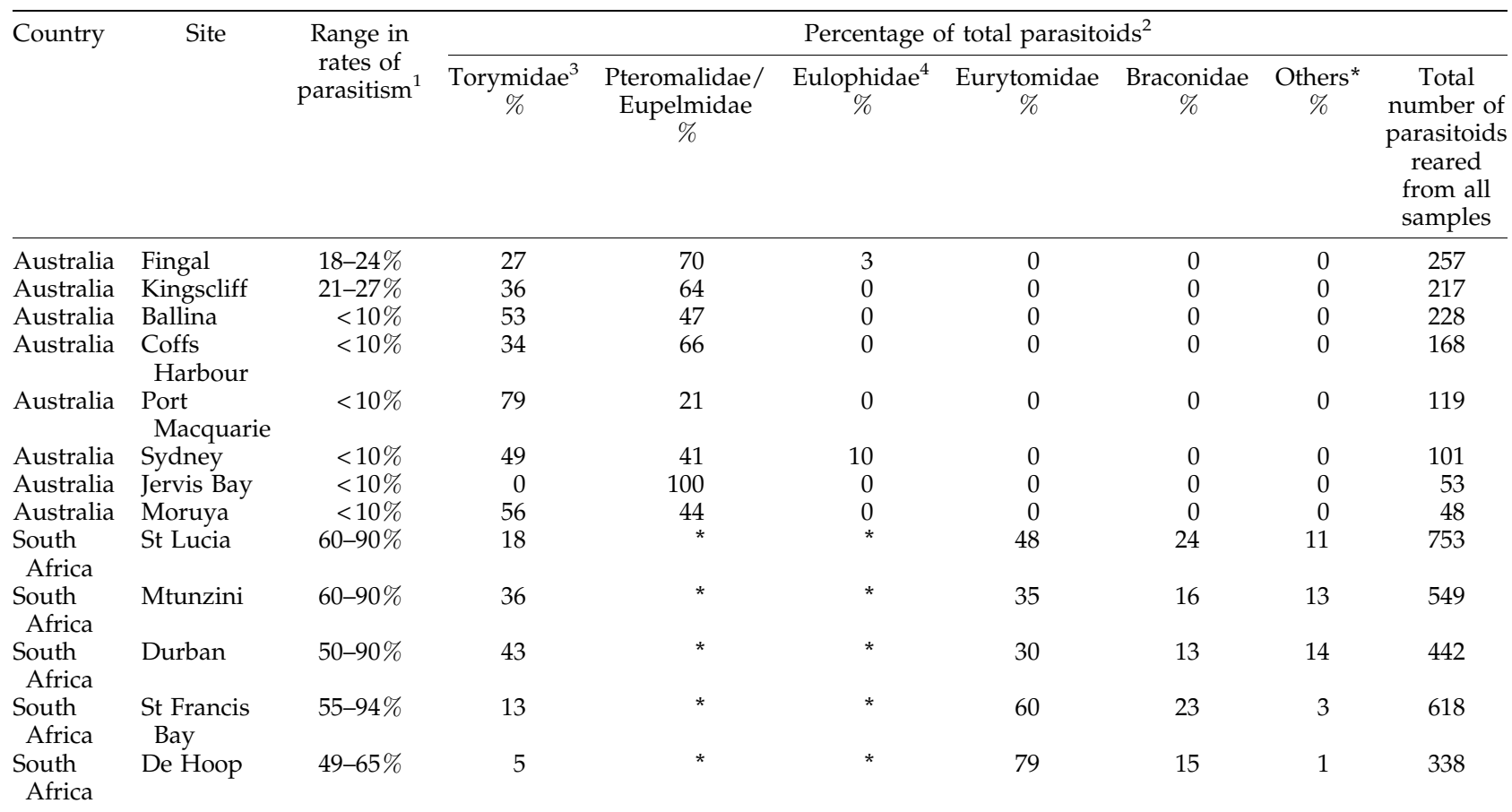

1 Australian parasitism rates taken from this study (May samples 2003 and 2004). South African parasitism rates taken throughout the year from 1992-1994 (see Edwards et al., 1996).

* 'Others' includes a species of Pteromalidae (Pteromalus sp.), an Encyrtidae, two species of Eulophidae (one an Aprostocetus) and a second species of Torymoides.

2 Based on total parasitoids reared from samples collected at all times of year.

3 Torymoides sp. in South Africa, Megastigmus sp. in Australia.

4 Aprostocetus microcosmus.

flowerhead is approximately 12 , or 2.5 on the natural logarithmic scale.

\section{Parasitism}

A summary of parasitism at each site is provided in table 1, which also includes data from South Africa for comparison. Due to difficulty in readily distinguishing between some of the taxa, results in table 1 are presented for six broad groupings: Eurytomidae, Braconidae, Eulophidae, Torymidae, Pteromalidae/Eupelmidae and others. There is some overlap in categories since 'others' from South Africa includes some Pteromalidae, Eulophidae and Torymidae species; however, their numbers are a small percentage of the totals.

Four species of parasites were reared from M. polana larvae and pupae in Australia; Pteromalus sp. (Pteromalidae), Eupelmus sp. (Eupelmidae), Megastigmus sp. (Torymidae) and Aprostocetus microcosmus (Girault) (Eulophidae). In Australia, the parasitism rate of M. polana was below $10 \%$ after 1998 at the six most southern sites. Rates were higher at the two northern sites of Fingal and Kingscliff, reaching 27\% at Kingscliff in 2003 (fig. 11). The difference between South
Africa and Australia was in the overall parasitism rates, which were below $30 \%$ in Australia and mostly between $49 \%$ and $94 \%$ in South Africa (table 1). Also, in Australia there was an absence of two of the predominant groups in South Africa, the Eurytomidae and Braconidae.

\section{Discussion}

Mesoclanis polana has exceptional dispersal capabilities. Following the release of 127 individuals from quarantine in 1996, the species had colonised $1200 \mathrm{~km}$ of the NSW coast by 1998 (Edwards et al., 1999). This rapid dispersal was probably aided by strong coastal winds providing potential for long-distance flights. However, the fly clearly has an impressive ability to locate its host in new environments, on occasion attacking $100 \%$ of available flowerheads (fig. 3). This attack rate is considerably higher than that reported by Stuart et al. (2002) in a short-term study in NSW.

The number of eggs per flowerhead increased rapidly at northern and central NSW sites, with no evidence that an asymptote has been reached (fig. 5). Egg numbers in May are several times higher than those recorded in South Africa, 


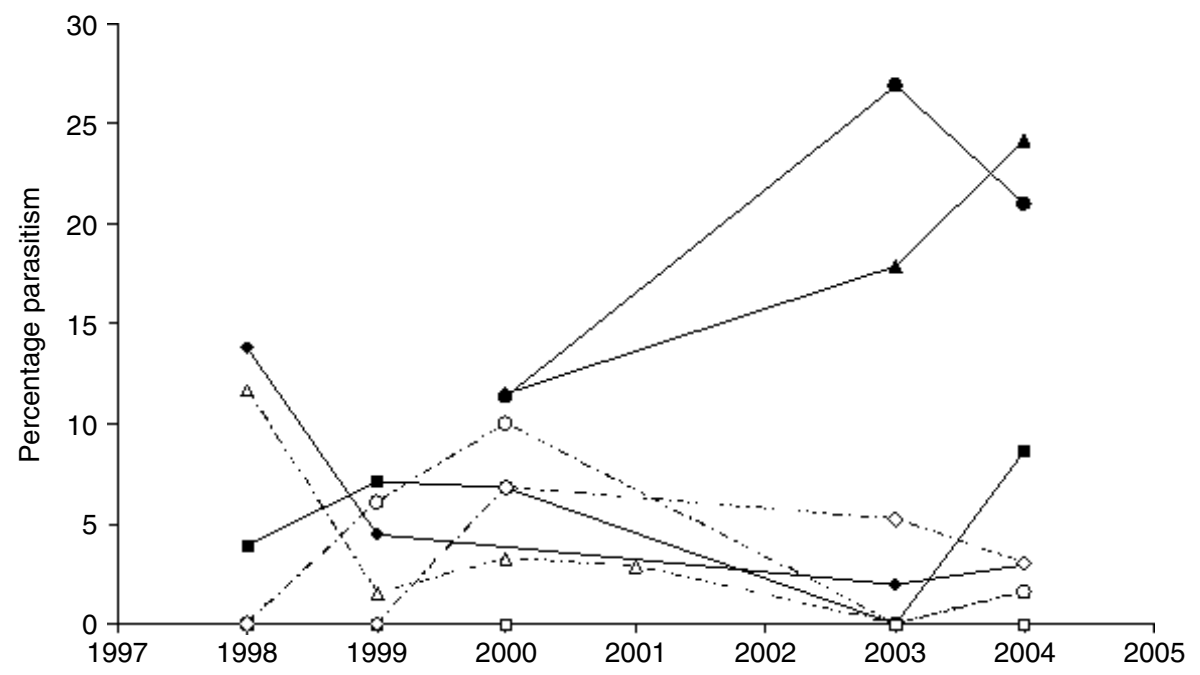

Fig. 11. Percentage parasitism of M. polana recorded at eight sites along the NSW coast in May of each year (from samples of 50-100 flowerheads on each occasion) $(-\mathbf{\Delta}-$, Fingal; $-\mathbf{-}-$, Kingscliff; $-\mathbf{\square}-$, Ballina; $-\longrightarrow-$, Coffs Harbour; -- $\triangle--$, Port Macquarie; -- $\bigcirc--$, Sydney; -- $\square--$, Jervis Bay; - $\diamond--$, Moruya).

where means below two eggs per flowerhead were recorded at a similar time of year at three sites during a two-year study (Edwards, 1998).

Destruction of $C$. $m$. rotundata seeds by $M$. polana in Australia has progressively increased since the insect was released in 1996, although strong temporal and spatial variation is apparent. A significant effect of latitude was detected, with May seed destruction levels exceeding $75 \%$ on four occasions at northern sites. By contrast, in the temperate infestations of C. m. rotundata at Jervis Bay and Moruya, M. polana populations have persisted, but seed destruction levels has settled at low levels.

Seed destruction by $M$. polana in May provided a reasonable estimate of the annual percentage seed destruction. A more reliable estimate of the annual seed destruction could be obtained by sampling every two weeks during peak seed production, that is, March to May at northern sites and April to June at southern sites. A similar sampling frequency could be undertaken during the secondary peak in November.

Eggs may be laid by several M. polana females in one flowerhead, providing the potential for destruction of all fertile ovules in that flowerhead. The maximum number of eggs recorded in one flowerhead in our study was 44, compared with a maximum in South Africa of 27 (Edwards \& Brown, 1997). Seed destruction increased with higher egg densities, although not at a constant rate. This was probably due to an asymptote of maximum ovule number being approached, but could also have indicated larval competition or interference at higher larval densities. It is unlikely to be a consequence of parasitism, since parasitoids emerge from $M$. polana larvae or pupae after their hosts have damaged developing ovules. Egg parasitoids may be involved, but our sampling regime would not have detected these.

Parasitoids can limit the establishment and impact of biological control agents. We have recorded four species of hymenopteran parasitoids utilising $M$. polana larvae and pupae in Australia. These species, or closely related species, were already known from native Australian tephritids feeding in flower-heads of native and exotic Asteraceae (Edwards et al., 1996).

Based on a pre-release survey of tephritids from Australian Asteraceae, Edwards et al. (1996) predicted that if $M$. polana acquired parasitoids in Australia, the fauna would be less diverse and less effective than that in South Africa. In accordance with these predictions, we found the major parasitoids to be generalists from the families Torymidae and Pteromalidae. We also recorded a eupelmid species and a cosmopolitan eulophid species. In particular, Edwards et al. (1996) predicted that M. polana was extremely unlikely to acquire specialist parasitoids such as Eurytoma sp. (Eurytomidae) and Psyttalia sp. (Braconidae), which have a significant impact on M. polana in South Africa where parasitism is $50-90 \%$ for most of the year (table 1). Although M. polana has acquired parasitoids throughout its range in Australia, the attack rate is generally less than $10 \%$, except at the two most northern sites (fig. 11).

This is possibly the first time that predictions on potential parasitism of a biological control agent have been made, which have then been followed up after the agent's release. It is only through such studies that progress can be made into the scientific basis underpinning biological control and the selection of agents.

An introduced herbivore that acquires native parasitoids may have indirect affects on native herbivores, mediated by the shared parasitoids. Willis \& Memmot (2005) used a foodweb approach to model possible impacts of $M$. polana on native Australian tephritids, but further experimentation is required to determine if this is occurring.

In South Africa, M. polana activity is synchronised with the flowering and fruiting phenology of its host, C. $m$. rotundata (Edwards, 1998). A similar pattern of synchronisation appears to have been maintained in Australian $M$. polana populations, where C. $m$. rotundata has two flowering and fruiting peaks, the largest occurring in autumn and a smaller peak occurring in late spring-early summer. Between these peaks, lower levels of flower 
production occur, providing a food source and oviposition sites for $M$. polana that may facilitate persistence of this multivoltine insect in the field throughout the year.

In South Africa, M. polana is restricted to the subtropical region of KwaZulu Natal and Mozambique, north of latitude $31^{\circ} \mathrm{S}$ (Edwards \& Brown, 1997). This distribution is well matched to northern coastal areas of NSW and southern Queensland. However, in Australia, the distribution of M. polana has extended further south than in South Africa, to about $37^{\circ} \mathrm{S}$ (Edwards et al., 1999). This may be due to lack of competition from other Mesoclanis species or to less pressure from parasitism. Nonetheless, the cooler climate of southern NSW is not optimal for M. polana, where seed destruction levels remain low at $2-18 \%$. It is possible that development of $M$. polana is adversely affected by cooler temperatures, more so than bitou bush, resulting in phenological asynchrony between host and herbivore at more southerly latitudes.

Edwards \& Brown (1997) suggested that M. magnipalpis Bezzi would be a suitable biological control agent against C. $m$. rotundata in southern NSW, and possibly for C. m. monilifera in Victoria, based on its more southerly distribution on both these subspecies in South Africa. The low abundance of M. polana in southern NSW observed in our study was not unexpected, and it is clear that the introduction of a second Mesoclanis species such as M. magnipalpis, more climatically suited to the area, could improve the level of seed destruction.

Small releases of M. magnipalpis in Victoria and South Australia on C. m. monilifera from 1999 to 2003 were unsuccessful. Edwards \& Brown (1997) recommended that $M$. magnipalpis should initially be released on $C$. $m$. rotundata in the southern part of its Australian range, since it is more abundant on C. $m$. rotundata in South Africa than on other subspecies with a shorter flowering season. From there, it could be redistributed to $C$. $m$. monilifera in southern Australia. Further attempts to establish M. magnipalpis are now required and are more likely to be successful if larger numbers of insects are released (Adair \& Bruzzese, 2000). These proposals have recently been adopted, with large releases of M. magnipalpis made on C. m. rotundata in 2005 in southern NSW (T. Morley, personal communication).

If $M$. magnipalpis establishes in southern NSW, a unique opportunity will exist to monitor interactions between the two Mesoclanis species. The species have similar resource utilisation strategies, except that $M$. polana may pupate in ovules or the receptacle, whereas $M$. magnipalpis invariably pupates in ovules (Edwards \& Brown, 1997). In South Africa, $M$. magnipalpis is the dominant Mesoclanis species in the southern range of C. $m$. rotundata, where M. polana does not occur (Edwards \& Brown, 1997). Thus, it is possible that M. magnipalpis could displace M. polana in southern NSW (Jervis Bay and Moruya) and provide a higher level of seed destruction than $M$. polana currently achieves in this region. In South Africa, the distribution of $M$. magnipalpis extends north to $29^{\circ} \mathrm{S}$ where it coexists with M. polana. However, its abundance is extremely low in these subtropical regions (Edwards \& Brown, 1997), and it is unlikely to impact on $M$. polana in central or northern NSW.

Chrysanthemoides monilifera produces substantially larger seed loads in Australia than in its native South African range (Noble \& Weiss, 1989; Weiss, 1993), a feature that contributes to the invasiveness of $C$. monilifera in Australia. A reduction in viable seed production of more than $95 \%$ may be required for successful suppression of C. monilifera in Australia (Noble \& Weiss, 1989). While low seed-destruction rates may have no impact on the population dynamics of C.m. rotundata (Kriticos et al., 2004), previous attempts at predictive modelling have grossly under-estimated the actual level of seed destruction caused by $M$. polana, particularly in northern New South Wales. Our study has shown that pre-dispersal levels up to $86 \%$ may be achieved in Australia, although not consistently and not at all sites. However, such levels of damage will undoubtedly reduce the seed bank, slow the rate of spread of bitou bush and slow the rate of reinvasion after removal by other methods. While a $95 \%$ reduction in seed production may be an unrealistic target for a single biological control agent, the prospects improve through use of multiple species of herbivores or pathogens with complimentary feeding action. This was the strategy behind the introduction of eight biological control agents for C. monilifera in Australia between 1989 and 2001. Several of these insects have established but, apart from M. polana, to date, they have had limited impact on seed production of C. $m$. rotundata (Holtkamp, 2002).

Recent progress with testing and importation of two agents that damage the leaves of $C$. monilifera, the eriophyiid mite Aceria neseri (Morley, 2004) and the systemic rust fungus Endophyllum osteospermi (Doidge) A.R. Wood (Wood \& Crous, 2005), may provide potential for further weakening the seeding capacity of C. monilifera in Australia. Biological control, used in an integrated manner with conventional control techniques, continues to form the basis of the national control program for C. monilifera in Australia (Adair \& Edwards, 1996; ARMCANZ, 2000; Downey et al., 2007).

\section{Acknowledgements}

We thank the following people for facilitating access to field sites: Graham Harding (Eurobodalla Shire Council), Rebecca Rudd and Martin Fortescue (Booderee National Park), Jamie Erskine and Sharon Evans (Botany Bay National Park) and staff of the Department of Environment and Conservation. We thank Phil Stephenson and Suzanne Young for assistance with field sampling. We are particularly grateful to Kim Hare for her meticulous dissections of flower and fruit samples. We thank Drs Ian Naumann and John La Salle for expert taxonomic advice on the hymenopteran parasitoids. Bruce McCorkell (NSW DPI) is thanked for helpful comments on the data. Valuable comments on the manuscript were provided by Drs Rachel McFadyen, Adele Reid and John Hosking.

\section{References}

Adair, R.J. \& Bruzzese, A.S. (2000) Evaluation and host specificity of two seed flies Mesoclanis polana and M. magnipalpis (Diptera: Tephritidae): biological control agents for Chrysanthemoides monilifera (Asteraceae) in Australia. Bulletin of Entomological Research 90, 467-474.

Adair, R.J. \& Edwards, P.B. (1996) An attack strategy against Chrysanthemoides monilifera, a weed of native vegetation in Australia. pp. 429-434 in Moran, V.C. \& Hoffmann, J.H. (Eds) Proceedings of the IX International Symposium on Biological Control of Weeds. University of Cape Town, 19-26 January 1996, Stellenbosch, South Africa. 
ARMCANZ (2000) Weeds of National Significance Bitou Bush and Boneseed (Chrysanthemoides monilifera ssp. rotundata and monilifera) Strategic Plan. Launceston, Tasmania, National Weeds Strategy Executive Committee.

Buckely, Y.M., Brockerhoff, E., Langer, L., Ledgard, N., North, H. \& Rees, M. (2005) Slowing down pine invasion despite uncertainty in demographic and dispersal. Journal of Applied Ecology 42, 1020-1030.

Crawley, M.J. (1992) Seed predators and plant population dynamics. pp. 157-192 in Fenner, M. (Ed.) The Ecology and Regeneration of Plant Communities. Wallingford, UK, CAB International.

Downey, P.O., Holtkamp, R.H., Ireson, J.E., Kwong, R.M. \& Swirepik, A.E. (2007) A review of the Chrysanthemoides monilifera biological control program in Australia: 1987-2005. Plant Protection Quarterly 22, 24-32.

Edwards, P.B. (1998) Seasonal abundance and parasitism of Mesoclanis seed flies (Diptera: Tephritidae) in South Africa, and implications for the biological control of Chrysanthemoides monilifera (Asteraceae) in Australia. Bulletin of Entomological Research 88, 407-414.

Edwards, P.B. \& Brown, E.M. (1997) Mesoclanis seed flies (Diptera: Tephritidae) on Chrysanthemoides (Asteraceae) in South Africa: distribution, attack strategy and impact on seed production. Bulletin of Entomological Research 87, 127-135.

Edwards, P.B., Adair, R.J. \& Holtkamp, R.H. (1996) Seedhead tephritids and their parasitoids - can predictions be made about likely parasitism of tephritids introduced into Australia for biological control of Asteraceae? pp. 153-164 in Moran, V.C. \& Hoffmann, J.H. (Eds) Proceedings of the IX International Symposium on Biological Control of Weeds. University of Cape Town, 19-26 January 1996, Stellenbosch, South Africa.

Edwards, P.B., Holtkamp, R.H. \& Adair, R.J. (1999) Establishment and rapid spread of the bitou seed fly Mesoclanis polana in eastern Australia. Australian Journal of Entomology 38, 148-150.

Hoffmann, J.H. \& Moran, V.C. (1998) The population dynamics of an introduced tree, Sesbania punicea, in South Africa, in response to long-term damage caused by different combinations of three species of biological control agents. Oecologia 114, 343-348.

Holtkamp, R.H. (2002) Impact of bitou tip moth, Comostolopsis germana, on bitou bush in New South Wales. pp. 405-406 in Spafford-Jacob, H., Dodd, J. \& Moore, J.H. (Eds) Proceedings of the 13th Australian Weeds Conference. Plant Protection Society of Western Australia, 8-13 September 2002, Perth, Western Australia.

Holtkamp, R.H., Edwards, P.B. \& Adair, R.J. (1999) Biological control of bitou bush: just around the turn of the millennium? pp. 667-669 in Bishop, A.C., Boersma, M. \& Barnes, C.D. (Eds) Proceedings of the 12th Australian Weeds Conference. Tasmanian Weed Society, Devonport, 12-16 September 1999, Hobart, Tasmania.

Julien, M. \& Griffiths, M.W. (Eds) (1998) Biological Control of Weeds: A World Catalogue of Agents and Their Target Weeds. 4th Edn. 108 pp. Wallingford, UK, CAB International.

Kriticos, D.J., Stuart, R.M. \& Ash, J.E. (2004) Exploring interactions between cultural and biological control techniques: modelling bitou bush (Chrysanthemoides monilifera ssp. rotundata) and a seed fly (Mesoclanis polana). pp. 559-566 in Cullen, J.M., Briese, D.T., Kriticos, D.J., Lonsdale, W.M., Morin, L. \& Scott, J.K. (Eds) Proceedings of the XI International
Symposium on Biological Control of Weeds. Canberra, Australia, 27 April-2 May 2003, CSIRO Entomology.

Louda, S. (1982) Limitations of the recruitment of the shrub Haplopappus squarrosus (Asteraceae) by flower- and seedfeeding insects. Journal of Ecology 70, 43-53.

Louda, S. (1983) Seed predation and seedling mortality in the recruitment of a shrub, Haplopappus venetus (Asteraceae) along a climatic gradient. Ecology 64, 511-521.

Louda, S. (1989) Predation in the dynamics of seed regeneration. pp. 25-52 in Leck, M.A., Parker, C.T. \& Simpson, R.L. (Eds) Ecology of Seed Banks. San Diego, Academic Press.

Louda, S. \& Potvin, M. (1995) Effect of inflorescence-feeding insects on the demography and lifetime fitness of a native plant. Ecology 76, 229-245.

Maron, J.L. \& Gardner, S.N. (2000) Consumer pressure, seed versus safe-site limitation, and plant population dynamics. Oecologia 124, 260-9.

Moore, L.R. (1978) Seed predation in the legume Crotalaria - I. Intensity and variability of seed predation in native and introduced populations on C. pallida. Oecologia 34, 185-202.

Morley, T. (2004) Application for approval to release the erineum-inducing Aceria sp. ex Chrysanthemoides monilifera (L.) Norl. spp. monilifera (boneseed leaf buckle mite): A potential biological control agent for Chrysanthemoides monilifera. Victorian Department of Primary Industries ISBN 1741462428.

Myers, J.H. \& Risley, C. (2000) Why reducing seed production is not necessarily translated into successful biological weed control. pp. 569-581 in Spencer, N.R. (Ed.) Proceedings of the International Symposium on Biological Control of Weeds. Montana, USA, 4-14 July 1999, Montana State University, Bozeman, Montana.

Neser, S. \& Kluge, R.L. (1986) The importance of seed attacking agents in biological control of invasive alien plants. pp. 285-293 in MacDonald, I.A.W., Kruger, F.J. \& Ferrar, A.A. (Eds) The Ecology and Management of Biological Invasions in Southern Africa. Cape Town, Oxford University Press.

Noble, I.R. \& Weiss, P.W. (1989) Movement and modelling of buried seed of the invasive perennial Chrysanthemoides monilifera in coastal dunes and biological control. Australian Journal of Ecology 14, 55-64.

Payne, R.W., Murray, D.A., Harding, S.A., Baird, D.B. \& Soutar, D.M. (2007) GenStat for Windows (10th edn) Introduction. Hemel Hempstead, VSN International.

Sheppard, A.W., Hodge, P., Paynter, Q. \& Rees, J. (2002) Factors affecting invasion and persistence of broom Cystisus scoparius in Australia. Journal of Applied Ecology 39, 721-734.

Sperens, U. (1997) Fruit production in Sorbus aucuparia L. (Rosaceae) and pre-dispersal seed predation by the apple fruit moth (Argyresthia conjugella Zell.). Oecologia 110, 368373.

Stuart, R.M., Kriticos, D.J. \& Ash, J.E. (2002) Modelling the biological control of bitou bush (Chrysanthemoides monilifera: Asteraceae) by Mesoclanis polana (Tephritidae). pp. 591-594 in Proceedings of the 13th Australian Weeds Conference. Plant Protection Society of Western Australia, 8-13 September 2002, Perth, Western Australia.

Thomas, J. \& Leys, A. (2002) Strategic management of bitou bush (Chrysanthemoides monilifera ssp. rotundata (L.) T.Norl.). pp. 586-590 in Proceedings of the 13th Australian Weeds Conference. Plant Protection Society of Western Australia, 8-13 September 2002, Perth, Western Australia. 
van Klinken, R.D., Kriticos, D., Wilson, J. \& Hoffmann, J. (2004) Agents that reduce seed production - essential ingredient or fools folly? pp. 621-622 in Cullen, J.M., Briese, D.T., Kriticos, D.J., Lonsdale, W.M., Morin, L. \& Scott, J.K. (Eds) Proceedings of the XI International Symposium on Biological Control of Weeds. Canberra, Australia, 27 April-2 May 2003, CSIRO Entomology.

van Klinken, R.D., Colasanti, R. \& Buckley, Y.M. How sensitive is weed invasion to seed predation? in Julien, M.H., Sforza, R., Bon, M.C., Evans, H.C., Hatcher, P.E., Hinz, H.L. \& Rector, B.G. (Eds) Proceedings of the XII International Symposium on Biological Control of Weeds. 22-27 April 2007, Wallingford, UK, CAB International (in press).

Weiss, P. W. (1993) Ecology of Chrysanthemoides monilifera in relation to control. pp. $2-5$ in Holtkamp, R.H. (Ed.) Proceedings of a National Workshop on Chrysanthemoides monilifera. New South Wales Agriculture, Tamworth, 28-30 April, 1993, Port Macquarie.
Weiss, P. W., Adair, R. J. \& Edwards, P. B., Winkler, M. A. \& Downey, P. O. (2008) Chrysanthemoides monilifera subsp. monilifera (L.) T. Norl. and subsp. rotundata (DC.) T. Norl. Plant Protection Quarterly 23, 3-14.

Willis, A. J. \& Memmott, J. (2005) The potential for indirect effects between a weed, one of its biocontrol agents and native herbivores: A food web approach. Biological Control 35, 299-306.

Wood, A. R. \& Crous, P. W. (2005) Morphological and molecular characterization of Endophyllum species on perennial asteraceous plants in South Africa. Mycological Research 109, 387-400.

Zimmermann, H. G. (1992) Two seed-feeding bruchids as part of an integrated approach for the control of Prosopis spp., Mesquite, in South Africa. pp. 453 in Delfosse, E.S. \& Scott, R.R. (Eds) Proceedings of the VIII International Symposium on Biological Control of Weeds. 2-7 February 1992, Melbourne, DSIR/CSIRO. 
Reproduced with permission of the copyright owner. Further reproduction prohibited without permission. 